\title{
Development of a high country winter-feed option using irrigated nitrogen- fertilised tall fescue
}

\author{
K.M. POLLOCK', D. SCOTT and J.S. ROBERTSON ${ }^{2}$ \\ AgResearch, PO Box 60, Lincoln \\ 'Present address: Department of Plant Science, PO Box 84, Lincoln University, Canterbury \\ 'Present address: Alex McDonald (Merchants) Ltd, Christchurch
}

\section{Abstract}

A 2 ha 6-year trial on pure stands of irrigated Grasslands Roa tall fescue compared the effect of high (600-300 kg N/ha/yr as urea) and moderate (300-150) nitrogen rates split over either 2- or 4weekly application, on hay production, some summer grazing and autumn regrowth prior to winter and fed to pregnant ewes on the same plots. Annual yields averaged 13.8 t DM/ha with a $24 \%$ advantage to high N. Pregnant ewes break fed a mixed allowance of hay and grass regrowth lost c. $2.4 \%$ body weight over a 8 -week winter period. There was thinning of the stands under high $\mathrm{N}$ and long summer regrowth period. It was considered better to forego some of the winter feed potential for some summer grazing, or a further hay cut, to maintain stand density.

K eywords: Festuca arundinacea, high country, irrigation, winter feed

\section{Introduction}

On most high country pastoral properties stock carrying potential is limited by the ability to produce winter feed. The traditional method was summer-saved native pasture. Fertilised special-purpose pastures for hay have been developed, with recently inclusion of irrigation on some properties, to guarantee adequate winter hay supplies. Winter crops of green-feed cereals or brassicas have been used to a lesser extent depending on availability of fertile soils. Both latter options require high annual expenses in resources and time to grow, harvest during the summer and feed out in the winter. Thus there is a desire to develop methods producing standing winter feed. In the high country, grasses that retain their feeding value and are more frost tolerant that legumes, are still difficult to establish. Vartha \& Clifford (1971 a\&b) developed a method whereby the more frost tolerant legume species, like alsike clover and tetraploid red clover, were summer saved and fed off in early winter to increase sheep body weight, thereby allowing lower feeding rations in the later part of winter.
With the development of more reliable methods of establishing grasses (Pollock 1989), interest has turned to the use of grass/legume summer-saved pasture, preferably grass dominated, for standing winter feed. This is an extension of the all-grass wintering system developed in other parts of New Zealand. With the 3-4 months of zero pasture growth in the high country, the standing feed has to be accumulated prior to winter and is better described as a 'feed bank' system (Allan et al. 1985). Even then there is a need for high soil fertility to gain adequate grass proportions, and the problem of the legume component lost through frosting in early winter.

The present trial explores a further option using nitrogen-fertilised grass only and combinations of summer saved hay, fed with autumn regrowth during the winter period. The trial was based on Grassland Roa tall fescue (Festuca arundinacea Schreb.) which had been developed in New Zealand for increasing summer and autumn yields of dryland pastures (Anderson 1982; Anderson et al. Brock et al. 1982, $1 \quad 9 \quad 8 \quad 3$; Lancashire_\&_Brock-1983).-The-extension-to standing winter feed was partly by reference to its high winter feed quality in previous high country high fertiliser and irrigated trials (Scott \& Maunsell 1981, 1986), and because it has been widely used for winter feed in the USA.

\section{$M$ ethods}

The 6-year trial was conducted at the Wolds Station in the Mackenzie Country on 2 ha of newly border-dyked land of a high-country yellow-brown earth (Wolds silt loam). Roa tall fescue was spring drilled at $30 \mathrm{~kg} / \mathrm{ha}$ with $100 \mathrm{~kg} / \mathrm{ha}$ sulphur coated urea and $500 \mathrm{~kg} / \mathrm{ha}$ sulphur fortified $(23 \%$ S) superphosphate in the first year, and irrigated at 2-to 3-week intervals as required during the growing season. The trial was given a year to establish with $50 \mathrm{~kg} \mathrm{~N} / \mathrm{ha}$ as urea during the summer and light grazing in the first autumn.

The four treatments were an unbalanced unreplicated factorial of 2 fertiliser nitrogen levels by 2 frequencies of split application. The high $\mathrm{N}$ level (4 plots) received $600 \mathrm{~kg} \mathrm{~N} / \mathrm{ha}$ as urea in the second and third year, $500 \mathrm{~kg} \mathrm{~N} / \mathrm{ha}$ in the fourth year, $400 \mathrm{~kg} \mathrm{~N} / \mathrm{ha}$ in the fifth year, and $300 \mathrm{~kg} \mathrm{~N} / \mathrm{ha}$ in the sixth year. The 
moderate $\mathrm{N}$ level (2 plots) received half the high level. The $\mathrm{N}$ was split between either fortnightly or monthly applications between October and April.

Hay was taken from all treatments in December as small bales and the number recorded. Two of the high$\mathrm{N}$ plots had a further hay cut or grazing in the second and fourth years. Plots were then allowed to regrow until winter. In later years there was also common grazing in early spring and February. Pasture herbage mass was determined from capacitance probe measurements calibrated for current conditions.

The hay and standing regrowth were fed to pregnant half bred ewes on the same plots as the hay came from, in approximate weekly breaks with back fencing, between June and August. The ewes were weighed at the start, mid point and end. Flock size was determined by the total feed available on each plot. The daily ration varied between years from 0.9 to $1.3 \mathrm{~kg} \mathrm{DM} /$ ewe/day but was the same for each treatment. Ewes were given 2-4 days on each grass break before hay was supplied.

\section{Results}

There was no difference in yields between the 2- and 4-weekly $\mathrm{N}$ applications and these plots became, in effect, replications for the levels of $\mathrm{N}$ application.

The annual yields averaged 13.8 tonne DM/ha with a $24 \%$ advantage to the high $\mathrm{N}$ level, though with the small number of plots, this was not significant relative to the $\mathrm{N}$ level by nitrogen frequency interaction $(\mathrm{P}=0.15)$ (Figure 1). There was an increase in yield between the two $\mathrm{N}$ levels with the incremental being 8.6, 14.7, 16.4, 6.8 and $13.8 \mathrm{~kg} \mathrm{DM} / \mathrm{kg} \mathrm{N}$ for the second to sixth year respectively. The December hay cuts made up from a quarter to a third of the annual yields.

It became apparent after the second year that tall fescue, under the high $\mathrm{N}$ levels and long regrowth periods, was causing self shading and thinning of the sward. This was the reason for both lowering the $\mathrm{N}$ levels in later years and imposing additional grazings firstly in the spring before closing for hay, and again in February prior to saving for the autumn regrowth period. While this maintained the annual yields, it resulted in a lesser portion being available for winter feeding as hay or saved pasture.

Even with the high applied nitrogen levels there was clover ingress into the swards in the later years from adjacent paddocks.

Over winter, with hay and break feeding of autumn regrowth, a ration of $1 \mathrm{~kg} \mathrm{DM} /$ day gave only minimal sheep live weight losses (Table 1). A higher rate of 1.3 $\mathrm{kg}$ used in the second year resulted in apparent wastage and no less live weight loss. There was frosting of the standing grass with only about half the material still green in the middle of the winter.

Table 1 Variation in mean values between years in winter feeding.

\begin{tabular}{lcc}
\hline Range & Mean & Range \\
\hline Sheep weight loss (kg) & & \\
$\quad$ high nitrogen & 1.2 & -0.2 to 2.3 \\
$\quad$ low nitrogen & 0.6 & -0.5 to 1.6 \\
Sheep weight (kg) & 44.0 & 4 \\
Stocking rate (sheep/ha) & 175.0 & $94-375$ \\
Duration (days) & 49.0 & $31-63$ \\
Feeding ration (kg/day) & 1.0 & $0.91-1.3$ \\
\% pasture & 58.0 & $51-73$ \\
\hline
\end{tabular}

\section{Discussion}

Overseas results indicate that irrigated tall fescue swards respond linearly to $\mathrm{N}$ up to rates of $500-600 \mathrm{~kg}$ $\mathrm{N} /$ ha/year though at higher rates the $\mathrm{N}$ fertiliser efficiency is less (Hallock et al. 1973; Eck et al. 1981ab). This was confirmed in the present trial. The better response to $\mathrm{N}$ in both yield and stand persistence when applied in small doses reported by Eck et al. (1981a) was the reason for including the feature in the present trial. The results indicate that monthly application were acceptable, and in the interest of simplicity of farm management higher rates at even longer intervals should be investigated.

Previous high country winter feeding trials have indicated that it is not possible to increase ewe body weights 
over the winter and that weights can only be maintained or slightly reduced (Coop \& Clark 1966; Thompson 1971; Vartha \& Clifford 1971 a\&b; Daly \& Allan 1985). Hence the slight weight losses over the winter in the trial were regarded as acceptable.

The suggestion for the trial approach came from American work, where baled hay is left in the paddock, thus limiting transport costs. Also the last potential hay cut for the season is foregone and allowed to accumulate as standing feed, and in the winter animals are allowed access to both and gradually move from the standing grass to the hay as winter progresses (Barker et al. 1965; Taylor \& Templeton 1976; Archer \& Decker 1977 a\&b; Balasko 1977; Ocumpaugh \& Matches 1977; Eck et al. 1981b). The practice also limits nutrient loss from the hay paddocks.

The difference in the present trial was to include the feed efficiency of break feeding, as used elsewhere in New Zealand. Also as the trial was irrigated there was a need to move the hay from the paddock, and for experimental purposes the need to use small bales. In large-paddock farming, large bales could be placed on wide dykes clear of irrigation water. We would have reservations on initial unrestricted access to all regrowth and hay, with the trade-off being between the cost of material and labour for controlled break fencing, compared with the lower cost but more probable rapid decline in the standing grass through trampling and fouling as animals selectively grazed it in the early winter. The advantage of break feeding, especially if there 2- to 3-day delay in giving hay after movement onte new grass_break, is that it gives.better_utilisation of the feed and allows control of feeding ration through the winter, particularly towards the later stages of pregnancy.

In farming terms the trial showed that high grass yields can be obtained using $\mathrm{N}$ fertiliser and that it is a winter feed option. The results show there is no need to go to the highest $\mathrm{N}$ levels that were used in this trial. Also there is some need to forego some of the winter potential in the interest of maintaining the stand density. Some spring and summer grazing is desirable to promote tillering of the tall fescue and to control weeds. Some harvesting for hay or grazing is important during the main growth period in midsummer so the stand does not become overgrown with consequent thinning. Break feeding and back fencing, though labour intensive, allows rationing of feed and gives better spring regrowth.

\section{ACKNOWLEDGEMENTS}

Mr J. Murray for use of land and stock, Petrochem for urea fertiliser, and Mr G.P. Royds, B.L. Sutherland and L.A. Maunsell for technical assistance.

\section{REFERENCES}

Allan, B.E.; Lowther, W.L.; Walton, P.J. 1985. Planning, establishment and management of pastures in high country. In Burgess, R.E. \& Brock, J.L. (eds) Using herbage cultivars. Grasslands Research and Practice Series 3: 17-21.

Anderson, L.B. 1982. 'Grassland Roa' tall fescue (Festuca arundinacea Schreb.) New Zealand journal of experimental agriculture 10: 269-273.

Anderson, L.B.; Brock, J.L.; Boyd, A.F.; Harris, A.J.; Ryan, D.L. 1982. 'Grasslands Roa' tall fescue: herbage dry matter production and quality under mowing. New Zealand journal of experimental agriculture 10: 275-280.

Archer, K.A.; Decker, A.M. 1977. Autumn accumulated tall fescue and orchard grass. I. Growth and quality as influenced by nitrogen and soil temperature. Agronomy journal 69: 601-605.

Barker, H.K.; Chard, J.R.A.; Hughes, W.E. 1965. A comparison of cocksfoot and tall fescue dominant swards for out-of-season production. Journal of the British Grasslands Society 20: 84-90.

Balasko, J.A. 1977. Effect of N, P and K fertilisation on yield and quality of tall fescue forage in winter. Agronomy journal 69: 425-428.

Brock, J.L. 1982. 'Grasslands Roa' tall fescue: dry matter production under grazing. New Zealand journal of experimental agriculture 10: 281-284.

Brock, J.L. 1983. 'Grasslands Roa' tall fescue: A review. Proceedings of the New Zealand Grassland Association-14:-74-80.

Brock, J.L; Anderson, L.B.; Lanchashire, J.A. 1982. 'Grasslands Roa' tall fescue: seedling growth and establishment. New Zealand Grassland Association 10: 286-289.

Coop, I.E.; Clark, V.R. 1966. The influence of live weight on wool production and reproduction in high country flocks. New Zealand journal of agricultural research 9:165- 181.

Daly, M.J.; Allan, B.E. 1985. Autumn saved pasture in a high frost environment. Proceedings of the New Zealand Grassland Association 46: 135-40.

Eck, H.W.; Wilson, G.C.; Tito Martinez 1981a. Tall fescue and smooth brome grass. I. Nitrogen and water requirements. Agronomy journal 73: 446452.

Eck, H.V.; Wilson, G.C.; Tito Martinez 1981b. Tall fescue and smooth brome grass. II. Effects of nitrogen fertilization and irrigation regimes on quality. Agronomy journal 73: 453-456.

Hallock, D.L.; Wolf, D.D.; Blaser, R.E. 1973. Reaction of tall fescue to frequent summer nitrogen applications. Agronomy journal 65: 81 1-812. 
Lancashire, J.A.; Brock, J.L. 1983. Management of new cultivars for dryland. Proceedings of the New Zealand Grassland Association 44: 61-73.

Ocumpaugh, W.R.; Matches, A.G. 1977. Autumnwinter yield and quality of tall fescue. Agronomy journal 69: 639-643.

Pollock, K.M. 1989. Grass establishment and performance on a high country soil fertilised' with nitrogen. New Zealand journal of agricultural research 32: 7-15.

Scott, D.; Maunsell, L.A. 1981. Pasture irrigation in the Mackenzie Basin. I. Species comparison. New Zealand journal of experimental agriculture 14: 19-24.

Taylor, T.H.; Templeton, W.C. 1976. Stockpiling kentucky bluegrass and tall fescue forage for winter pasturage. Agronomy journal 68: 235-239.

Thompson, K.F. 1971. High-country hogget management (3). Tussock Grasslands and Mountain Lands Institute Review 21: 36-41.

Vartha, E.W.; Clifford, P.T.P. 1971a. The feeding of sheep on part improved tussock grassland. Tussock Grasslands and Mountain Lands Institute Review 21: 36-41.

Vartha, E.W.; Clifford, P.T.P. 1971b. Nutrition of halfbred ewes in improved tussock grassland. Proceedings of $\mathrm{New}$ Zealand Society of Animal Production 31: 97-104. 